[Regular Paper]

\title{
Decomposition of Benzothiophene, Dibenzothiophene, and Their Derivatives in Subcritical and Supercritical Water with Alkali
}

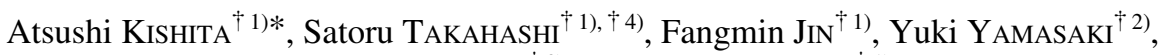 \\ Takehiko MORIYA $^{\dagger 3}$, and Heiji ENOMOTO ${ }^{\dagger 1)}$ \\ †1) Graduate School of Environmental Studies, Tohoku University, Aobayama 20, Aoba-ku, Sendai 980-8579, JAPAN \\ $\left.{ }^{2}\right)$ Osaka Prefectural College of Technology, 26-12 Saiwai-cho, Neyagawa, Osaka 572-8572, JAPAN \\ $\dagger 3)$ R\&D Center, Tohoku Electric Power Co., Inc., 2-1 Nakayama 7-chome, Aoba-ku, Sendai 981-0952, JAPAN
}

(Received August 17, 2004)

\begin{abstract}
Hydrothermal decomposition of thiophene derivatives in subcritical and supercritical water with alkali was studied to enhance desulfurization using a new on-site upgrading technology. Benzothiophene, dibenzothiophene, and derivatives (BTs and DBTs) can be decomposed by hydrothermal reaction with alkali in a temperature region where thermal decomposition is difficult. The ease of decomposition is influenced by the type and concentration of the alkali solution. Decomposition in $\mathrm{KOH}$ solution is the most complete, and occurs at a certain alkali concentration.

The reaction is sensitive to the pressure in supercritical water. Moreover, the reaction products of hydrothermal decomposition obtained in the present study differ to those by the hydrodesulfurization method (HDS) previously reported by other researchers. These results suggest that the mechanisms of decomposition are different and hydrothermal decomposition is preceded by ionic reaction. The ease of decomposition of BTs and DBTs is influenced by the molecular structure, similar to the trends seen in HDS.
\end{abstract}

\section{Keywords}

Supercritical water, Subcritical water, Benzothiophene, Dibenzothiophene, Desulfurization

\section{1. はじめに}

次世代炭化水素資源として期待されるオイルサンドの開発に おいて，カナダでは実用性の高い油層内採収技術としてSAGD (Steam Assisted Gravity Drainage) 法の開発が進展しており，実 規模生産を想定した輸送方法と，採収されたオイルサンド油 （ビチューメン）の高品質化処理方法の検討が急務となってい る。

これらの問題の基本的な対策として, ビチューメンをパイプ ライン輸送可能なレベルまで, オンサイトで低粘度化すること が重要である。また，多少なりとも品質を向上させることが望 ましく，かつSAGD法の規模である産油量 1 2万bbl/d 以下の 生産現場を対象とした処理技術であることも要点である。

そこで, SAGD法において産出される流体が高温の熱水と重 質油の混合物であることに着目し，この産出流体をオンサイト に設置した反応器に導入し, 水の超臨界状態まで昇温・昇圧し て水熱反応により低粘度化する技術，いわゆるアルカリ超臨界 水熱法の開発を目的として，工学的パラメーターの影響拉よび 低粘度化機構に関して基礎的な検討を行った ${ }^{1)}$ 。この研究では,

* To whom correspondence should be addressed.

* E-mail: kishita@mail.kankyo.tohoku.ac.jp

${ }^{\dagger 4}$ (Present) Technology Research Center, Japan Oil, Gas and Metals National Corp., 1-2-2 Hamada, Mihama-ku, Chiba 261-0025, JAPAN
パイプライン輸送可能なレベルの油が得られ，また生成油の低 粘度化に伴い脱硫も進行しており, 生成油中の硫黄含有率は初 期の值に対して半分近くまで減少した。さらに，同時に脱バナ ジウムも進行しており, 初期值の $1 / 10$ まで低下することが示 された。また，ビチューメンの粘度低下および脱硫に及ぼす反 応時間, 反応温度, 水密度, アルカリ濃度の影響から, 生成油 の改質は, ビチューメン中の比較的高分子量の成分が主として 炭素とへテロ原子との結合などの比較的弱い結合が熱的に解離 して低分子化し, 水が生成分子の安定化（あるいはラジカル同 士の再結合反応抑制）の役割を果たしている反応初期の比較的 速い反応と, その後の比較的ゆっくりとした反応によって起 こっていることが示唆された ${ }^{11}$ 。

また，反応時間をさらに長くすると，生成油中の硫黄含有率 の変化は少ないにもかかわらず，ビチューメンに元来含まれて いない低分子の硫黄化合物が多くみられるようになった2)。こ れらの硫黄化合物はアルキル基を有するベンゾチオフェン （BT）およびジベンゾチオフェン（DBT）類であった。これら の硫黄化合物は反応時間とともに増加しており, 超臨界水中で も比較的安定であると考えられるが, 水密度を高くした場合や 高濃度のアルカリの存在下では緩やかではあるが減少する傾向 がみられ, 水素ガスや高価な触媒を用いることなしに分解でき る可能性が示唆された ${ }^{2)}$ 。しかし，BT，DBT類のアルカリ水熱 反応による分解性については未解明である。そこで, 本報では 
これらの BT 類, $\mathrm{DBT}$ 類のアルカリ水熱反応における分解性に ついて検討し，ビチューメンをアルカリ超臨界水熱法により改 質する場合の硫黄の反応挙動について考察した。

高温・高圧の水とビチューメンの反応については, AOSTRA (Alberta Oil Sands Technology and Research Authority)によって も研究されてきた。そのなかで, ビチューメン中に存在すると 考えられるアリファティックとアロマティックの硫黄化合物の モデル化合物としてテトラヒドロチオフェンとチオフェンを用 いて，水熱分解実験を行っている。その結果，モデル化合物で 実験を行った場合に生成したガスとビチューメンで実験を行っ た場合の生成ガスの成分が同じであることから，C-S 結合の開 裂が分解反応の開始段階である ${ }^{3)}$ と報告している。また，水蒸 気攻法実施時に $\mathrm{H}_{2} \mathrm{~S}$ が生成し，これが大気中に放出されること が環境問題となっており，これを解決するために， $\mathrm{H}_{2} \mathrm{~S}$ の前駆 体である硫黄化合物について，そのモデル硫黄化合物の分解実 験から $\mathrm{H}_{2} \mathrm{~S}$ の生成を制御する基本的な知見を得ようとしてい る。C-S-Cまたは C-SHの結合をもつ9種類の硫黄化合物を $250^{\circ} \mathrm{C}$ および $300^{\circ} \mathrm{C}$ でシクロヘキサンおよび水中で分解実験を 行い, 分解率および反応後の生成物により評価している。これ によると, 大気に放出される $\mathrm{H}_{2} \mathrm{~S}$ の量を最小にするには可能な 限り低温の水蒸気で回収する必要がある ${ }^{4)}$ と報告している。さ らに，460 $\mathrm{C}$ において難分解な硫黄化合物である BTおよび千 オフェンの分解を水， $15 \%$ のギ酸水溶液， $15 \%$ のギ酸ナトリ ウム水溶液中で行ったが，ほとんど分解しない5) と報告してい る。また, Olobunmi らの) も，オイルサンドから超臨界水を用い て油分を抽出する際の脱硫抒よび脱窒素の可能性について検討 している。超臨界水を反応溶媒として, $400^{\circ} \mathrm{C}, 22.1 \mathrm{MPa}$ の条 件でキノリン，BT，メチルチオベンゾチアゾール等をモデル 化合物として分解実験を行っており, 硫黄・窒素が単独でしか 含まれない場合よりも両者が混在するようなへテロ化合物の方 が分解しやすいこと等を述べている。しかし， BTについては 9時間の反応でも $90 \%$ 以上残存して㧍り，水のみではほとんど 分解が進まないことや水を加えない熱分解では分解されないこ とを報告している。

\section{2. 実験}

\section{1. 実験試料}

別報2) で報告したビチューメンの水熱反応により生成する BTおよび DBT類としてはメチル-BT, DBT（以下， $\mathrm{C}_{1} \mathrm{BT}$, $\mathrm{C}_{1} \mathrm{DBT}$ と略記), ジメチル-あるいはエチル-BT, DBT（以下 $\mathrm{C}_{2} \mathrm{BT}, \mathrm{C}_{2} \mathrm{DBT}$ と略記), トリメチル-, ジメチル-エチルーあるい はプロピル-BT, DBT (以下, $\mathrm{C}_{3} \mathrm{BT}, \mathrm{C}_{3} \mathrm{DBT}$ と略記) が検出さ れているが，メチル基の位置については不明である。しかし， $\mathrm{C}_{1} \mathrm{BT}$ および $\mathrm{C}_{2} \mathrm{BT}$ としてそれぞれ3本と7本のピークが分離・ 検出されているなど, 検出されたピークの数から多くの位置に アルキル基を有する $\mathrm{BT}$ 類, $\mathrm{DBT}$ 類が存在するものと考えられ る。これらのことを参考に，また入手の容易なものを対象とす ることにして，実験試料を選択した。

まず，モデル化合物としてこれらの物質の主骨格構造物質で ある BTおよびDBTを用いることにした。また，アルキル-BT およびDBTとして，5-メチルベンゾチオフェン（5-MBT）お よび2,8-ジメチルジベンゾチオフェン $(2,8-\mathrm{DMDBT})$ を選択し,
合計 4 種類を使用した。これらの試薬を用いてアルカリ超臨界 水熱法によるビチューメン改質油 ${ }^{2)}$ 中の BT, DBT類を同定し た結果, BTとDBTは検出されなかったが, 他の 2 種類は存在 が確認された。

加部ら ${ }^{7)}$ は, アラビアンライト直留軽油中に 42 種類のアル キル側鎖を有する BT類掞よび 29 種類の DBT類が含まれてい ると報告している。また, 馬ら ${ }^{8)}$ は, 軽油中の硫黄化合物につ いて, 触媒を用いて水素化分解を行い, 反応速度定数の大きさ で比較し, 硫黄化合物はアルキル-BT類 $>4,6$ 位以外にアルキ ル基を有するアルキル-DBT類 $>4$ 位にアルキル基を有するア ルキル-DBT類 $>4,6$ 位にアルキル基を有する DBT類の四つに 分類している。この分類に従うと, BT と DBTのほかに前 2 者 に属するものを使用することになる。

BTおよびDBTにはそれぞれ和光純薬工業（株）の一級 （95\% 以上）および特級（98\% 以上）の試薬を用いた。また, 5-MBTは東京化成工業（株）の純度 $98 \%$ 以上，㧍よび $2,8-$ DMDBT は Lancaster Synthesis 社の純度 $96 \%$ 以上のものを使用 した。それぞれの硫黄化合物に含まれる不純物全てを同定する ことはできなかったが, GC/MS 分析により BTおよび5-MBT には $\mathrm{C}_{1} \mathrm{BT}, 2,8-\mathrm{DMDBT} に は \mathrm{C}_{1} \mathrm{DBT}$ と $\mathrm{C}_{3} \mathrm{BT}$ が不純物として含 まれていることが分かった。しかし，実験にはそのまま使用し

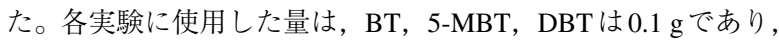
2,8-DMBTは $0.05 \mathrm{~g}$ である。また, これらの物質は常温で水に は不溶であり, ヘキサンには可溶である。

\section{2. 反応溶媒}

反応溶媒は別報1) と同じくアルカリ水溶液として, $\mathrm{NaOH}$, $\mathrm{KOH}, \mathrm{LiOH}$ 水溶液を用い, アルカリの種類について比較した。 また，アルカリの有無について比較するために $\mathrm{NaCl}$ 水溶液も 使用した。それぞれ試薬 (和光純薬工業 (株) 製) を蒸留水に 所定の濃度で溶解させて用いた。

\section{3. 実験方法}

実験装置には既報 ${ }^{1)}$ の誘導加熱炉とインコネル 600 製のバッ チ式反応容器 (内容積 $45 \mathrm{ml}$ ) を用いた。しかし, 既報のビ チューメンを用いての実験では, ビチューメンの粘度が高いた めかくはん用にボールを使用したが, 本実験では使用しなかっ た。

実験方法は以下のようである。まず，所定量の反応物とアル カリ水溶液を反応容器に入れ, 共存する酸素の影響を除くため 容器内の気相をアルゴンで置換し, 密閉する。反応容器を誘導 加熱炉に設置し, 容器を震とう・かくはんしながら $40^{\circ} \mathrm{C} / \mathrm{min}$ の昇温速度で加熱する。所定の時間経過後, 反応容器を誘導加 熱炉から素早く取り出し, ファンで強制空冷して室温まで冷却 する。反応時間は所定の温度に達してから誘導加熱炉より取り 出すまでの時間とした。その後, 反応容器を静かに開け, 抽出 溶媒としてへキサンを $10 \mathrm{~g}$ 加える。再び反応容器を閉めて, 容 器内の反応後の物質を十分抽出するために 15 分間震とう・か くはんした。その後, 溶液を分液ロートでへキサン相と水相に 分離し, GC/MS 拈よびGC/AED（原子発光検出器）によるへ キサン相の定性・定量分析および GC/FIDによる未反応物質 （出発物質）の定量分析を行った。

なお, 水充填率を室温に扔ける使用水体積と反応容器容積の 比として定義し, 超臨界水中における反応パラメーターとして 


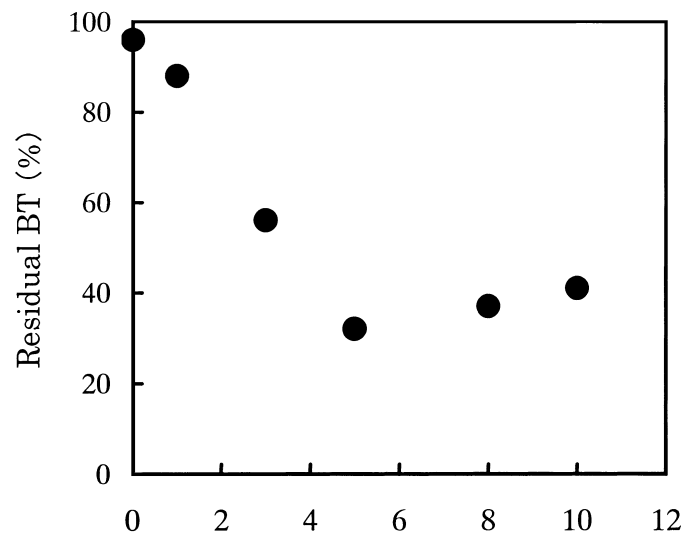

Concentration of $\mathrm{NaOH}\left(\mathrm{mol} \mathrm{dm}^{-3}\right)$

Fig. 1 Influence of $\mathrm{NaOH}$ Concentration on the Hydrothermal Decomposition of $\mathrm{BT}\left(300^{\circ} \mathrm{C}, 60 \mathrm{~min}\right.$, water fill $\left.20 \%\right)$

その影響も検討した。

\section{4. 分析方法}

へキサン相の定量および定性分析に使用したGC/FID, GC/MS およびGC/AEDの GCは同一の仕様にしてある（ともに Hewlett-Packard社製)。このうち, GCの設定条件について記す と以下のようである。

カラム: HP-1 (cross-linked dimethylpolysiloxane)

$30 \mathrm{~m} \times 0.25 \mathrm{~mm} \times 1 \mu \mathrm{m}$ film thickness

カラム流量: $1.0 \mathrm{~m} / / \mathrm{min}$

トータル流量: $100 \mathrm{~m} / / \mathrm{min}$

注入口温度: $300^{\circ} \mathrm{C}$

検出器の温度: $300^{\circ} \mathrm{C}$

注入方法: スプリット注入（スプリット比 $1 / 100)$

オーブンの初期温度: $50^{\circ} \mathrm{C}$ (5 分間保持)

オーブンの昇温速度: $5^{\circ} \mathrm{C} / \mathrm{min}$

オーブンの最終温度: $300^{\circ} \mathrm{C}$

\section{3. 実験結果および考察}

\section{1. BT およびDBT の水熱分解性とアルカリ濃度の影響}

\subsection{1. $\mathrm{NaOH}$ 水溶液濃度の影響}

Fig. 1 に，BT残存率に及ぼす $\mathrm{NaOH}$ 水溶液濃度の影響を示 す。Fig. 1中には, 蒸留水中での分解実験結果についても0 $\mathrm{mol} \cdot \mathrm{dm}^{-3}$ として示してある。これから, 蒸留水中よりもアル カリ水溶液中の方が分解は進行し， $\mathrm{NaOH}$ 濃度を高くするとよ り分解が進行することがわかる。Fig. 1 に示した反応温度 $300^{\circ} \mathrm{C}$, 反応時間 $60 \mathrm{~min}$ の場合には, $\mathrm{NaOH}$ 濃度が $5 \mathrm{~mol} \cdot \mathrm{dm}^{-3}$ のとき分解が最も進行し, 残存率は $32 \%$ まで低下するが, $\mathrm{NaOH}$ 濃度がさらに高くなると分解が抑制される傾向がみられ る。この結果から, これ以後の実験では, 特に断らない限り 5 $\mathrm{mol} \cdot \mathrm{dm}^{-3}$ の $\mathrm{NaOH}$ 濃度で実験を行うことにした。

Fig. 2 に, 反応温度 $430^{\circ} \mathrm{C}$, 反応時間 $120 \mathrm{~min}$ とした場合の $\mathrm{NaOH}$ 濃度とDBT残存率の関係を示す。DBTの分解反応にお いても BTの分解反応と同様に $5 \mathrm{~mol} \cdot \mathrm{dm}^{-3}$ において残存率が極 值を示し，それ以上の濃度では残存率が増加した。この結果か

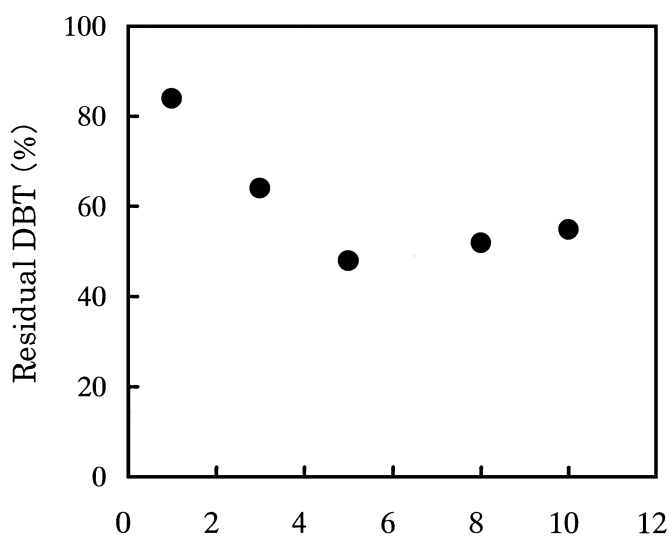

Concentration of $\mathrm{NaOH}\left(\mathrm{mol} \mathrm{dm}{ }^{-3}\right)$

Fig. 2 Influence of $\mathrm{NaOH}$ Concentration on the Hydrothermal Decomposition of DBT $\left(430^{\circ} \mathrm{C}, 120 \mathrm{~min}\right.$, water fill $20 \%)$

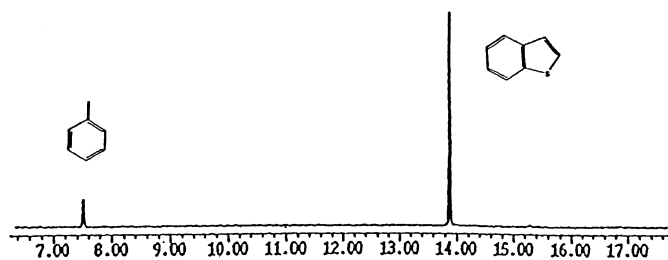

Retention time(min)

Fig. 3 GC/MS Chromatogram of the Hydrothermal Decomposition of $\mathrm{BT}\left(300^{\circ} \mathrm{C}, 60 \mathrm{~min}\right.$, water fill $20 \%$, $\mathrm{NaOH} 5 \mathrm{~mol} \cdot \mathrm{dm}^{-3}$ )

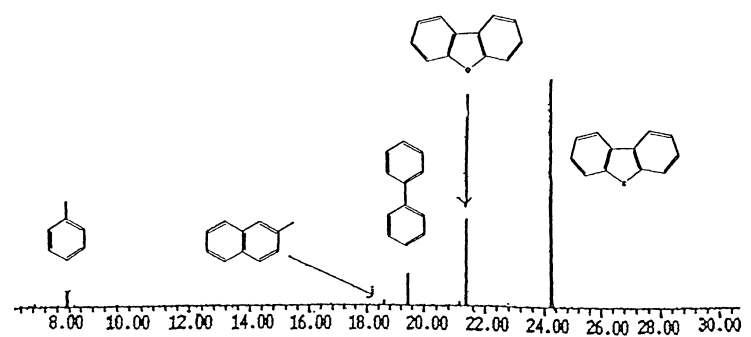

Retention time(min)

Fig. 4 GC/MS Chromatogram of the Hydrothermal Decomposition of DBT $\left(430^{\circ} \mathrm{C}, 120 \mathrm{~min}\right.$, water fill $20 \%, \mathrm{NaOH} 5 \mathrm{~mol} \cdot \mathrm{dm}^{-3}$ )

ら DBTについても, 特に断りがない限り, これ以降の実験で は最も分解が進行した $5 \mathrm{~mol} \cdot \mathrm{dm}^{-3}$ の $\mathrm{NaOH}$ 水溶液で実験を行う ことにした。

なお, 分解反応後の溶液中のへキサン抽出物について GC/MS クロマトグラムを Figs. 3 と 4 に示すが， BT の分解生成 物としてはトルエンの生成がみられ, DBTの分解生成物には トルエン，ビフェニル，ジベンゾフラン $(\mathrm{DBF})$ 等が検出され た。また脱硫後の硫黄は, 水溶液を塩酸酸性にした場合に発生 


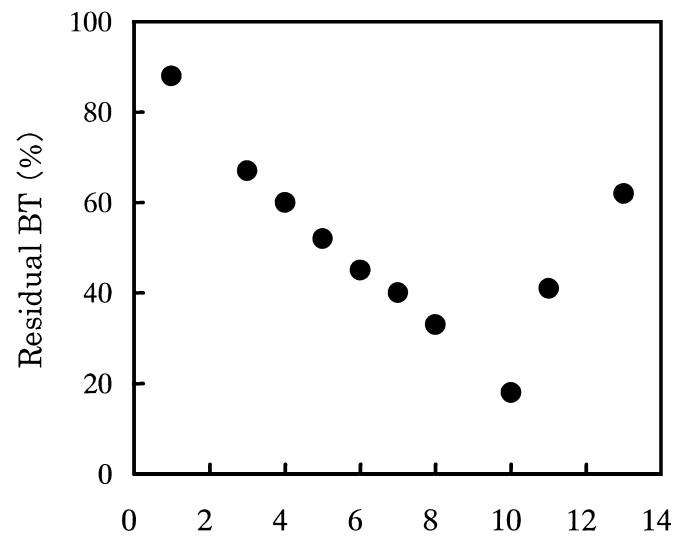

Concentration of $\mathrm{KOH}\left(\mathrm{mol} \mathrm{dm}^{-3}\right)$

Fig. 5 Influence of $\mathrm{KOH}$ Concentration on the Hydrothermal Decomposition of DBT $\left(415^{\circ} \mathrm{C}, 60 \mathrm{~min}\right.$, water fill $\left.20 \%\right)$

したガス中に $\mathrm{H}_{2} \mathrm{~S}$ の存在が確認されたことから，アルカリ水溶

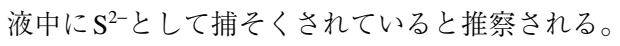

\subsection{2. $\mathrm{KOH}$ 水溶液濃度の影響}

別報1) で報告したオイルサンドの軽質化実験で効果の高かっ た $\mathrm{KOH}$ 水溶液でDBTの分解実験を行った。Fig. 5 に, 反応温 度 $415^{\circ} \mathrm{C}$, 反応時間 $60 \mathrm{~min}$ とした場合の $\mathrm{KOH}$ 濃度に対する DBT残存率を示す。KOHの濃度が高くなるに従ってDBTの分 解が進行し，ある濃度で極小值をとり，それ以上の濃度では逆 に残存率は増加し，分解が抑制され， $\mathrm{NaOH}$ の場合と同様の傾 向がみられた。しかし，極小值を示す濃度が $\mathrm{NaOH}$ と $\mathrm{KOH}$ と では異なっている。また，KOHの場合は，極小值を示す濃度 が明らかに特異点と考えられるような変化がみられる。このよ うなアルカリの影響に関しては，アルカリ濃度の増加が反応を 促進する効果 (触媒効果等) と溶液中での溶質の分散状態の変 化（塩析効果によるDBTの溶解度の低下等）により反応を抑 制する効果の両方をもたらし，これらがバランスしたことによ り現れた現象と推察される。

$\mathrm{KOH}$ 水溶液を用いた場合に極小值が得られた $10 \mathrm{~mol} \cdot \mathrm{dm}^{-3}$ は 実用上不向きと考えられる極めて高い濃度であり，また $\mathrm{NaOH}$ との比較のため, これ以降の $\mathrm{KOH}$ を用いる実験では, 特に断 らない限り $\mathrm{NaOH}$ の場合と同様に $5 \mathrm{~mol} \cdot \mathrm{dm}^{-3}$ とすることにし た。

\section{1.3. BT およびDBT の水熱分解性}

Fig. 6 に， $\mathrm{NaOH}$ を用いた場合の BT残存率に及ぼす反応時 間㧍よび反応温度の影響を示す。残存率 $50 \%$ で比較すると， 反応温度 $250^{\circ} \mathrm{C}$ では反応時間約 $600 \mathrm{~min}$ を要するのに対して, $320^{\circ} \mathrm{C}$ では約 $10 \mathrm{~min}$ で十分であることがわかる。Fig. 7に， DBT の残存率に及ぼす反応温度および反応時間の影響を示す。 反応時間 $240 \mathrm{~min}$ で比較すると, 反応温度 $400^{\circ} \mathrm{C}$ では残存率は $65 \%$ であるのに対して， $450^{\circ} \mathrm{C}$ では $8 \%$ 程度である。このよう に反応温度を高くすると, BT, DBTの両方とも急激に分解速 度が増加することがわかる。

また，温度以外を同一条件下として BTとDBTの分解率を比 較すると, BTは $250 \sim 300^{\circ} \mathrm{C}$ の水の亜臨界温度領域で分解する

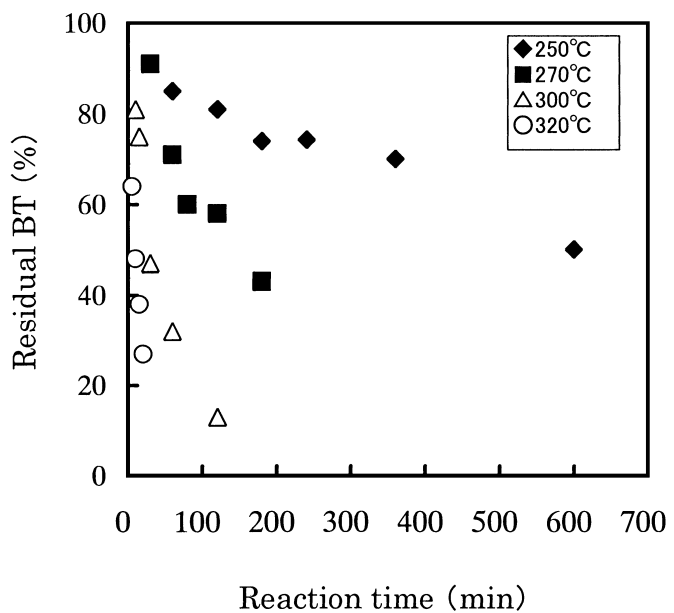

Fig. 6 Effect of Temperature on the Hydrothermal Decomposition of BT with $\mathrm{NaOH}$ (water fill 20\%, 5 $\mathrm{mol} \cdot \mathrm{dm}^{-3}$ )

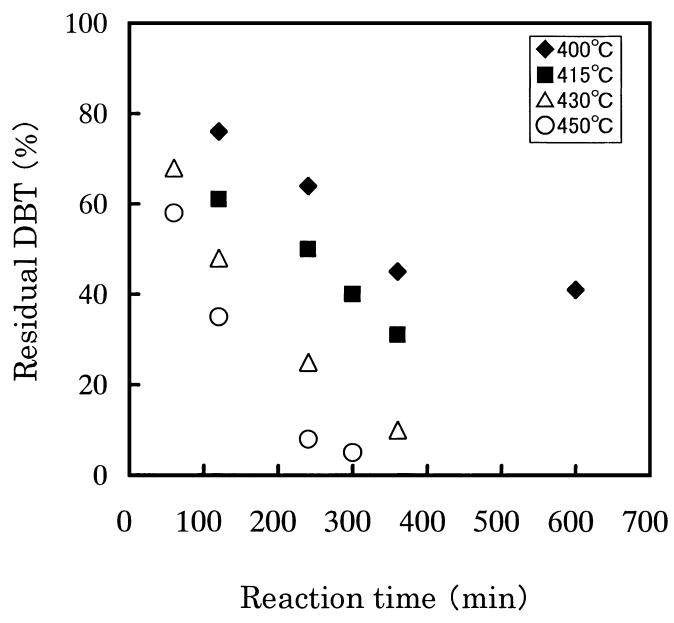

Fig. 7 Effect of Temperature on the Hydrothermal Decomposition of DBT with $\mathrm{NaOH}$ (water fill 20\%, 5 $\mathrm{mol} \cdot \mathrm{dm}^{-3}$ )

のに対して, DBTは $400^{\circ} \mathrm{C}$ 以上の超臨界温度領域でなければ分 解せず， DBTはBTよりも難分解であることがわかる。この傾 向は，水素化脱硫（HDS）に扔ける反応性と同様であり，アル カリ水熱分解においても分解の容易さは化合物の構造に依存す ることがわかった。

Fig. 8 に，KOHを用いた場合の反応温度および反応時間に 対するDBT残存率を示す。反応時間 $120 \mathrm{~min} に$ にいて, 反応温 度 $400^{\circ} \mathrm{C}$ では DBT残存率は約 $50 \%$ であるのに対して, $430^{\circ} \mathrm{C}$ ではほとんど分解している。ここでも, 反応温度を上げること により, 分解速度が急激に増加することが示されている。 $\mathrm{NaOH}$ 水溶液中での反応と比較すると, 反応温度 $430^{\circ} \mathrm{C}$, 反応 時間 $120 \mathrm{~min}$ では, $\mathrm{NaOH}$ の場合 DBT残存率は約 50\% であるが, $\mathrm{KOH}$ の場合ほとんど分解している。このことから，アルカリ の種類により DBTの分解の容易さが異なることがわかる。

\section{2. アルカリ水溶液の種類による分解性への影響}

$\mathrm{NaOH}$ 水溶液と $\mathrm{KOH}$ 水溶液では, 硫黄化合物の分解の容易 


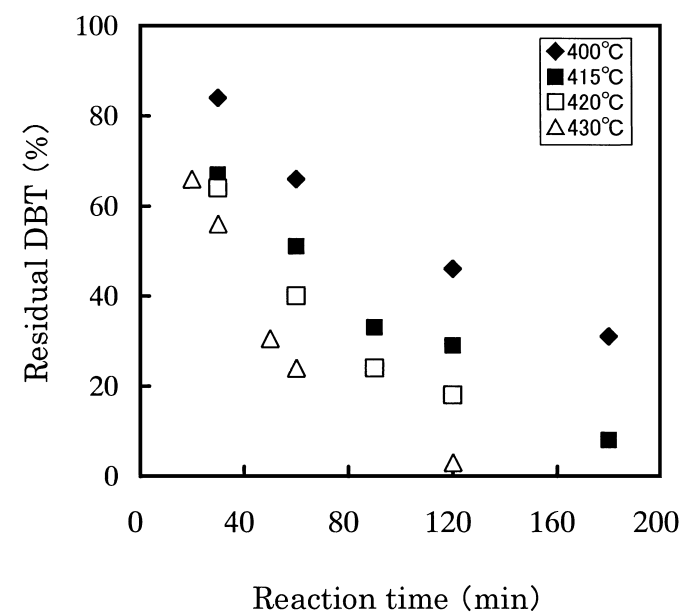

Fig. 8 Effect of Temperature on the Hydrothermal Decomposition of DBT with $\mathrm{KOH}$ (water fill $20 \%, 5$ $\mathrm{mol} \cdot \mathrm{dm}^{-3}$ )

Table 1 Effects of Electrolytes on Decomposition of DBT $\left(430^{\circ} \mathrm{C}\right.$, water fill $\left.20 \%\right)$

\begin{tabular}{lccc}
\hline & Reaction time [min] & Conc. $\left[\mathrm{mol} \cdot \mathrm{dm}^{-3}\right]$ & Residue [\%] \\
\hline $\mathrm{NaCl}$ & 60 & 5.0 & 97 \\
$\mathrm{NaOH}$ & 60 & 5.0 & 70 \\
$\mathrm{LiOH}$ & 120 & $4.6^{\mathrm{a}}$ & 97 \\
$\mathrm{NaOH}$ & 120 & 5.0 & 48 \\
$\mathrm{KOH}$ & 120 & 5.0 & 3.9 \\
\hline
\end{tabular}

a) saturated.

さが異なることがわかったので，ここではさらに他の電解質を 水に溶解させてDBTの分解の難易さを比較した。実験には $\mathrm{NaOH}, \mathrm{KOH}$ 水溶液に加えて, カチオンが異なる $\mathrm{LiOH}$ 水溶液, および $\mathrm{NaOH}$ とはアニオンが異なる $\mathrm{NaCl}$ 水溶液を用いた。 LiOH は溶解度が低いため, 実験では室温における飽和水溶液 $\left(4.6 \mathrm{~mol} \cdot \mathrm{dm}^{-3}\right)$ を用いた。

Table 1に, $\mathrm{LiOH}, \mathrm{NaOH}, \mathrm{KOH}$ おょび $\mathrm{NaCl}$ 水溶液中にお けるDBTの分解の容易さについての比較を示す。 $\mathrm{NaCl}$ と $\mathrm{NaOH}$ 水溶液を比較すると, $\mathrm{NaOH}$ 水溶液の方が反応速度大である。 アルカリ水溶液で比較すると分解反応速度は $\mathrm{KOH}>\mathrm{NaOH}>$ $\mathrm{LiOH}$ 水溶液の順である。これらのことから, $\mathrm{NaOH}$ 水溶液は 分解反応を進行させる上で $\mathrm{NaCl}$ 水溶液より効果的であり, ま た陽イオンも分解反応速度に影響していて, 本研究の範囲では $\mathrm{KOH}$ の効果が最も高いことがわかった。

\section{3. 分解反応性に及ぼす水充填率の影響}

Fig. 9に，KOHを用いた場合のDBTの分解に及ぼす水充填 率の影響を示す。水充填率が $5 \%$ （反応圧力約 $14 \mathrm{MPa}$ ）では残 存率は $95 \%$ 以上であり，ほとんど分解が進行していない。水 充填率を高くすると分解は進行し, 水充填率 $40 \%$ （反応圧力 約 $42 \mathrm{MPa}$ ）では残存率は $25 \%$ 程度になる。これは, 水充填率 （反応圧力あるいは水密度）の増加によりイオン積が大きく なったことなどの影響により，加水分解のようなイオン反応が 促進されたためと考えられる。

ビチューメンの低粘度化水熱処理に扔いても, 水充填率を増

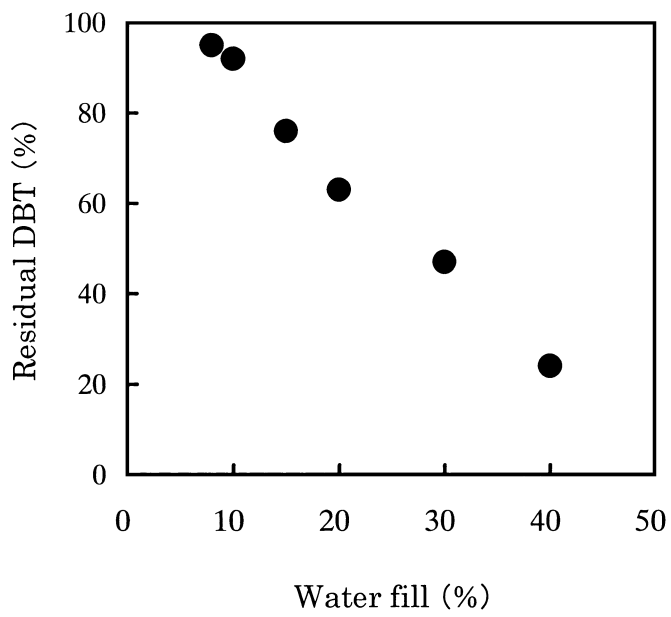

Fig. 9 Effect of Water Fill on the Hydrothermal Decomposition of DBT $\left(430^{\circ} \mathrm{C}, 60 \mathrm{~min}, \mathrm{KOH} 5 \mathrm{~mol}\right.$. $\left.\mathrm{dm}^{-3}\right)$

加させると脱硫が進行した ${ }^{2)}$ 。このような効果はイオン反応に おいて顕著にみられるが，たとえばプラスチックの水熱分解9 のようなラジカル反応に扔いては, 反応場がよりイオン的雾囲 気になることで, 逆にラジカル反応が進行しにくくなるという 負の影響としてみられる。したがって, 水充填率（反応圧力あ るいは水密度）による正の影響がみられるチオフェン類のアル カリ水熱分解反応はイオン反応的に進行していることを示唆し ている。

\section{4. 分解反応の速度論的検討}

上記の分解実験の結果から, 反応速度定数㧍よび見かけの活 性化エネルギーを求めた。ここでは本反応系が濃度の1次であ るとみなしてEq. (1)を用いた。

$$
-\mathrm{d} C / \mathrm{d} t=k C
$$

ここに,

$C$ 㕅応物質の濃度 $\left(\mathrm{mol} \cdot \mathrm{dm}^{-3}\right)$

$k$ 反応速度定数 $\left(\mathrm{min}^{-1}\right)$

である。Eq. (1) を積分し, 初期の反応物質の濃度を $C_{0}(\mathrm{~mol} \cdot$ $\left.\mathrm{dm}^{-3}\right)$ とすると,

$$
\begin{aligned}
& C=C_{0} \cdot \exp (-k t) \\
& \ln \left(C / C_{0}\right)=-k t
\end{aligned}
$$

となる。

Figs. 10 12 に, $\mathrm{NaOH}$ 水溶液中の $\mathrm{BT}, \mathrm{NaOH}$ 水溶液中の $\mathrm{DBT}$ および $\mathrm{KOH}$ 水溶液中の DBT の分解反応における反応時間 と $\ln \left(C / C_{0}\right)$ の関係を示す。これらからほぼ直線の関係が得られ, 直線の傾きから分解の反応速度定数を得ることができる。また， 反応速度定数は Eq. (4)のアレニウスの式で表されるとする。

$$
k=A \cdot \exp \left(-E_{\mathrm{a}} / R T\right)
$$

ここに,

$E_{\mathrm{a}}$ : 見かけの活性化エネルギー $\left(\mathrm{kJ} \cdot \mathrm{mol}^{-1}\right)$

$A$ : 頻度因子 $\left(\mathrm{min}^{-1}\right)$

$R$ : 気体定数 $\left(\mathrm{kJ} \cdot \mathrm{mol}^{-1} \cdot \mathrm{K}^{-1}\right)$

$T:$ 温度 $(\mathrm{K})$

である。 


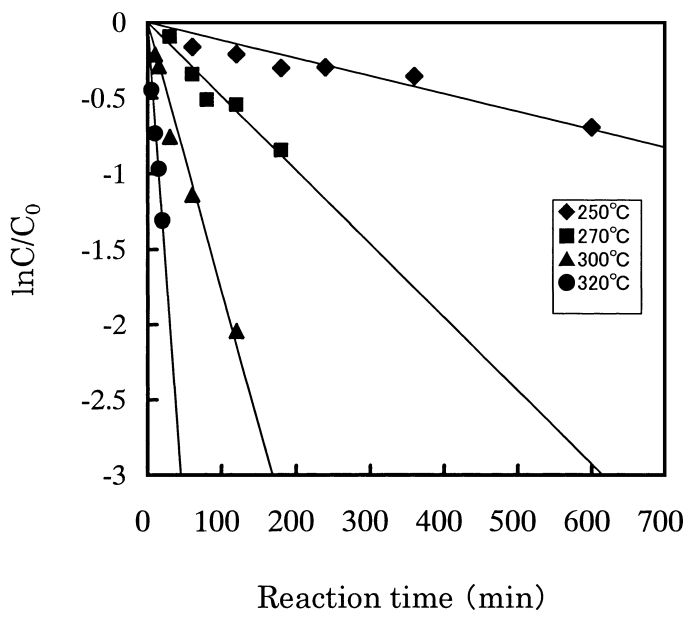

Fig. 10 Plot of $\ln C / C_{0}$ against Reaction Time at Various Reaction Temperatures for $\mathrm{BT}$ with $\mathrm{NaOH}$ (water fill $20 \%, 5 \mathrm{~mol} \cdot \mathrm{dm}^{-3}$ )

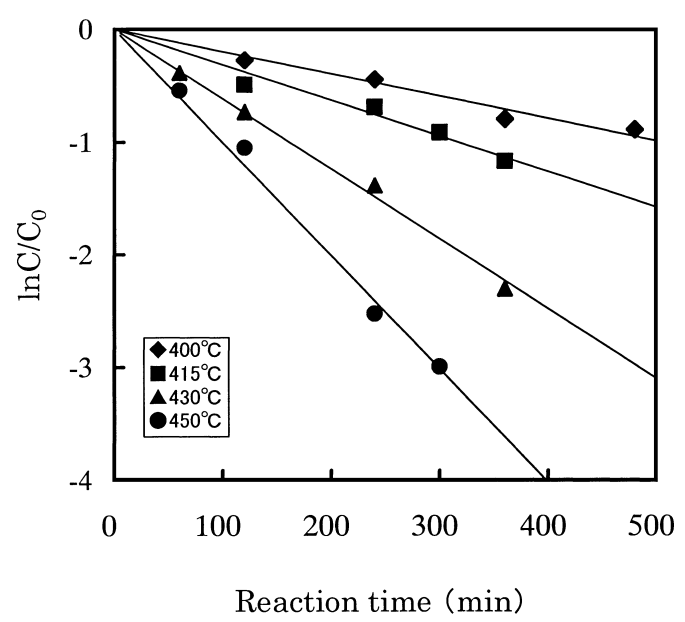

Fig. 11 Plot of $\ln C / C_{0}$ against Reaction Time at Various Reaction Temperatures for DBT with $\mathrm{NaOH}$ (water fill $20 \%, 5 \mathrm{~mol} \cdot \mathrm{dm}^{-3}$ )

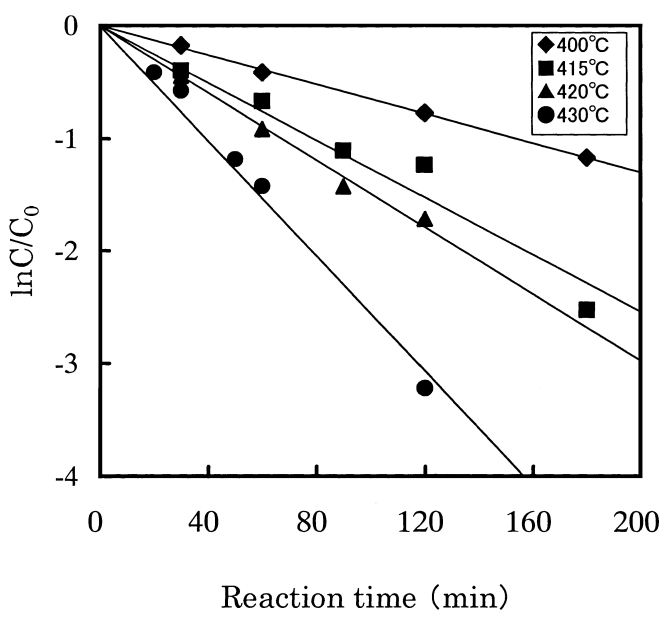

Fig. 12 Plots of $\ln C / C_{0}$ of DBT against Reaction Time at Various Reaction Temperatures for DBT with $\mathrm{KOH}$ (water fill $20 \%, 5 \mathrm{~mol} \cdot \mathrm{dm}^{-3}$ )

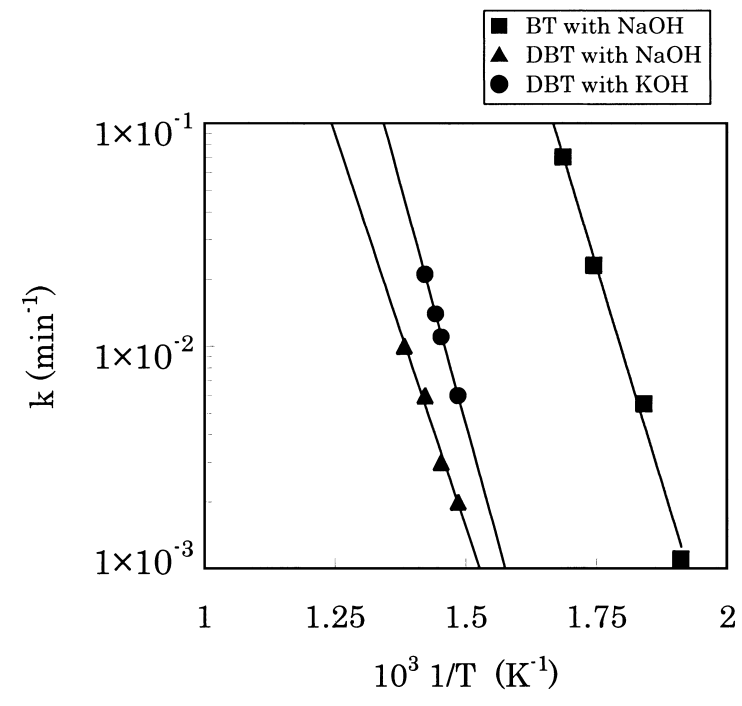

Fig. 13 Arrhenius Plots of the Hydrothermal Decomposition of BT with $\mathrm{NaOH}$, DBT with $\mathrm{NaOH}$, and DBT with $\mathrm{KOH}$

Fig. 13にアレニウスプロットを示す。これから，見かけの 活性化エネルギーおよび頻度因子を求めた。その結果を Table 2 に示す。BTはDBTよりも容易に分解するにもかかわらず, 見かけの活性化エネルギーが同程度の值になっているが, BT の高い分解速度は, BTの頻度因子が DBTよりも2けた程度大 きいことによって保たれている。

DBTの分解において, $\mathrm{NaOH}$ 水溶液と $\mathrm{KOH}$ 水溶液の見かけ の活性化エネルギーを比較すると, $\mathrm{KOH}$ の場合には見かけの 活性化エネルギーは約 $20 \mathrm{~kJ} \cdot \mathrm{mol}^{-1}$ 大きい。しかし, 分解の容 易さは $\mathrm{KOH}$ の場合に高く，これは $\mathrm{KOH}$ の場合の頻度因子が $\mathrm{NaOH}$ の場合の頻度因子より2けた程度大きいことで保たれて いる。

水素化脱硫処理（HDS）の見かけの活性化エネルギーは触媒 により表面解離吸着水素の活性が異なるため值に幅があり，お
Table 2 Results of Kinetic Analysis

\begin{tabular}{lcl}
\hline & $E_{\mathrm{a}}\left[\mathrm{kJ} \cdot \mathrm{mol}^{-1}\right]$ & $A\left[\mathrm{~min}^{-1}\right]$ \\
\hline BT with $\mathrm{NaOH}$ & 139 & $8.89 \times 10^{10}$ \\
DBT with $\mathrm{NaOH}$ & 139 & $1.11 \times 10^{8}$ \\
DBT with $\mathrm{KOH}$ & 160 & $1.55 \times 10^{10}$ \\
\hline
\end{tabular}

およそ30〜 $60 \mathrm{~kJ} \cdot \mathrm{mol}^{-1}$ と報告10),11) されているが，アルカリ水 熱分解の見かけの活性化エネルギーと比較すると $100 \mathrm{~kJ} \cdot \mathrm{mol}^{-1}$ 程度の差が存在する。このことについて考察してみる。Fig. 3 と Fig. 4 にBTおよびDBTの反応後の生成物について示した。 HDSにおける反応経路は水素化脱硫経路と直接脱硫経路に大 別され, $\mathrm{BT}$ の水素化脱硫経路ではその反応機構 ${ }^{10)}$ に従ってエ チルベンゼンが生成するが，Fig. 3 にはトルエンの生成がみら 


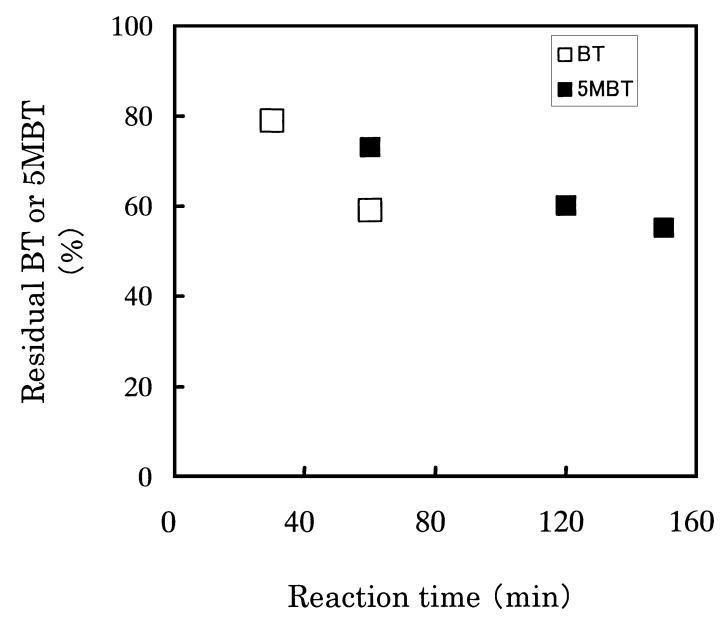

Fig. 14 Comparison of Hydrothermal Decomposition of BT and 5 -MBT $\left(270{ }^{\circ} \mathrm{C}\right.$, water fill $\left.20 \%, \mathrm{KOH} 5 \mathrm{~mol} \cdot \mathrm{dm}^{-3}\right)$

Table 3 Decomposition of DBT and 2,8-DMDBT in Supercritical Water with $\mathrm{KOH}$

\begin{tabular}{lc}
\hline & Residue [\%] \\
\hline DBT & 3.9 \\
2,8 -DMDBT & 52.9 \\
\hline
\end{tabular}

Reaction temp.: $430^{\circ} \mathrm{C}$, Reaction time: $120 \mathrm{~min}$, Water fill: $40 \%$, $\mathrm{KOH}$ conc.: $5 \mathrm{~mol} \cdot \mathrm{dm}^{-3}$.

れるのみである。また, DBTの水素化脱硫機構8)による生成物 はシクロヘキシルベンゼンやビシクロヘキシル等のベンゼン環 に水素付加した生成物であるが，Fig. 4 に示したアルカリ水熱 分解の場合には生成物中にベンゼン環が水素化された化合物が 検出されて㧍らず，トルエン，ビフェニル，ジベンゾフラン (DBF) 等が検出されている。これらのことは, HDSとアルカ リ水熱反応では異なる反応が起こっていることを示唆してお り，活性化エネルギーが大きく異なることもこれを支持してい ると考えられる。

\subsection{BT と 5-MBT，およびDBT と 2,8-DMDBT の水熱分解 の比較}

Fig. 14 に，BTと 5-MBTのアルカリ水熱分解の比較を示す。 反応温度 $270^{\circ} \mathrm{C}$, 反応時間 $60 \mathrm{~min}$ において, BTの残存率は約 60\% で5-MBTは約 75\% である。Table 3 にアルカリ水熱分解 におけるDBT と 2,8-DMDBTの残存率を示す。反応温度 $430^{\circ} \mathrm{C}$, 反応時間 $120 \mathrm{~min} に$ におて, DBTの残存率は $4 \%$ であるが 2,8 DMDBT は 53\% である。すなわち，どちらの場合もメチル基 を有する化合物の反応速度はメチル基を有さない化合物より小 さくなる。これらの傾向はHDS の場合と同様である。Houalla $ら^{12), 13)}$ は，固体触媒を用いたDBT類の水素化脱硫について DBT，4-MDBT，2,8-DMDBT，3,7-DMDBT 抒よび4,6-DMDBT を用いて反応速度を比較しており，反応条件によりアルキル基 を有さないDBTの相対的脱硫活性が2,8-DMDBT，3,7-DMDBT よりも低くなる場合があることを報告しているが，今回のアル カリ水熱分解の場合にはこのような傾向はみられなかった。
Table 4 Decomposition of BT and 5-MBT in Supercritical Water with $\mathrm{KOH}$

\begin{tabular}{lc}
\hline & Residual BT or 5-MBT [\%] \\
\hline BT & 0.23 \\
5-MBT & 1.3 \\
\hline
\end{tabular}

Reaction temp.: $430^{\circ} \mathrm{C}$, Reaction time: $100 \mathrm{~min}$, Water fill: $20 \%$, $\mathrm{KOH}$ conc.: $1 \mathrm{~mol} \cdot \mathrm{dm}^{-3}$.

3. 6. ビチューメンのアルカリ超臨界水熱改質反応における BT，DBT 類の反応挙動に関する考察

別報 ${ }^{2)}$ で報告したように, ビチューメンのアルカリ超臨界水 熱改質処理で, ビチューメンに元来含まれていないアルキルBTおよびアルキル-DBTが改質油中にみられたが， BT, DBT は見られなかった。また, アルキル-BTとアルキル-DBTとは 同程度の濃度であったが，わずかに分解が容易なアルキル-BT の方が多かった。これらの現象について以下に考察する。

上述のように, BT類はアルカリ水熱反応では $300^{\circ} \mathrm{C}$ 以下の 温度範囲でも分解する。しかし，別報 ${ }^{2)}$ で報告したように，ア ルキル基を有する BT類は水の超臨界領域におけるビチューメ ンの改質処理で改質油中に存在していた。そこで, ビチューメ ンのアルカリ超臨界水熱法で採用されている反応温度 $430^{\circ} \mathrm{C} に$ おける BTと 5-MBTの分解性について調べた。反応時間 100 minでのBTと 5-MBTの残存率を Table 4 に示す。どちらの場 合もほとんど分解しており, BT類の分解速度は高いことがわ かる。しかし, さらに詳細に相違を検討すると, 残存率は5MBTの方が1けた高く, ビチューメン中に含まれる少量の硫 黄化合物の分解について, この差が大きな意味をもつ場合もあ り得ると考えられる。

別報 ${ }^{2)}$ で報告したように，この条件でビチューメンの分解実 験を行った場合， $\mathrm{BT}$ は検出されず， $\mathrm{C}_{1} \mathrm{BT}$ 類， $\mathrm{C}_{2} \mathrm{BT}$ 類および $\mathrm{C}_{3} \mathrm{BT}$ 類の濃度はこの順に高くなり， $\mathrm{C}_{1} \mathrm{BT}$ 類は $0.02 \sim 0.1 \mathrm{wt} \%$ であった $\left(\mathrm{C}_{2} \mathrm{BT}\right.$ 類および $\mathrm{C}_{3} \mathrm{BT}$ 類の濃度はそれぞれ $0.06 \sim 0.15$, 0.07〜0.15 wt\% であった)。したがって, BTが検出されていな いのは, 分解率が1けた高いため生成しても分解したことによ る可能性も考えられる。その上, 水熱分解反応ではアルキル基 を有する化合物が生成する可能性が高く ${ }^{14)}$, たとえ BTが生成 したとしてもその量は多くなかったものと推察される。逆に, アルキル-BT類はBTよりも容易に生成し, さらにBTよりも分 解が困難であるため残留し，検出されたと考えられる。

DBT類についても, DBTが検出されなかったのは同様の理 由によると考えられる。他方，アルキル-DBT類については, $\mathrm{C}_{1} \mathrm{DBT}, \mathrm{C}_{2} \mathrm{DBT}, \mathrm{C}_{3} \mathrm{DBT}$ 間で濃度に有意な差がなく，かつ $\mathrm{BT}$ 類と同程度の低濃度であった ${ }^{2)}$ 。前述のように，アルキル-BT 類とDBT類では分解の容易さが大きく異なり, ビチューメン のアルカリ超臨界水熱処理ではアルキル-BT類は生成と分解が 同時に進行していると考えられるが，アルキル-DBT類は分解 が困難である。このことから，アルカリ水熱反応によりビ チューメン（高分子含硫黄化合物）から始めに生成する低分子 の硫黄化合物としてはBT類が多く, DBT類は少ないものと推 察される。換言すると, 別報1) で報告したように, ビチューメ ンのアルカリ超臨界水熱処理によって $4.6 \sim 4.7 \%$ の硫黄含有率 
が半分程度まで低下するが，本研究の結果は反応条件を適切に 制御することによって BT類の分解を促進し，その結果硫黄含 有率をさらに低下させることが可能であることを示唆してい る。

\section{4. まとめ}

本報では，ベンゾチオフェン（BT）類およびジベンゾチオ フェン（DBT）類のアルカリ水熱反応による分解性ならびに分 解反応について検討を行った。その結果，アルカリ水溶液中で は容易に分解が進行し，特に水素化脱硫ではBTよりも難分解 性とされているDBTの分解もアルカリ水溶液中では進行する など，水素ガス添加や特殊な触媒を用いずに硫黄化合物が分解 することが明らかになった。これらの結果をまとめると以下の ようである。

（1）BT類およびDBT類は, 熱的作用のみでは分解しない温度 域のアルカリ熱水中で分解する。

（2）アルカリ濃度の影響としては，ある濃度で残存率が最小と なる極值を示し，それ以上の濃度で残存率は大きくなるという 傾向を示した。また分解の容易さは，アルカリ水溶液の種類に より影響を受け， $\mathrm{KOH}$ 水溶液中での分解が最も容易であった。 （3）水の超臨界状態では反応圧力が高い方が分解反応は容易に 進行した。この結果は, 分解がイオン反応的に進行しているこ とを示唆している。

（4）BTおよびDBTの分解反応速度は反応温度の上昇により急 激に増加した。反応物の濃度に依存する一次の反応とすると, $\mathrm{BT}$ と $\mathrm{DBT}$ あるいは $\mathrm{NaOH}$ と $\mathrm{KOH}$ で大きな相違はなく, 見かけ の活性化エネルギーは $140 〜 160 \mathrm{~kJ} \cdot \mathrm{mol}^{-1}$ であった。

（5）BT拉よびDBTの水熱分解では，反応により生ずる生成物 が水素化脱硫法（HDS）の場合と異なっており，両者の反応機 構が異なることが示唆された。また，見かけの活性化エネル ギーの值も大きく相違しており，このことを支持していると考 えられる。
（6）BTはDBTよりも分解が容易に進行し，またメチル基を有 する硫黄化合物とメチル基を有さない硫黄化合物の分解の容易 さを比較すると, メチル基を有さない硫黄化合物の方が容易に 分解する。これらの傾向はHDS の場合と同様である。

\section{References}

1) Kishita, A., Takahashi, S., Kamimura, H., Miki, M., Moriya, T., Enomoto, H., J. Jpn. Petrol. Inst., 45, (6), 361 (2002).

2) Kishita, A., Takahashi, S., Kamimura, H., Miki, M., Moriya, T., Enomoto, H., J. Jpn. Petrol. Inst., 46, (4), 215 (2003).

3) Hyne, J. B., Clark, P. D., Clarke, R. E., Koo, J., Greidanus, J. W., Tyrer, J. D., Verona, D., Rizek, C., Int'l Conference on Heavy Crude and Tar Sands 2nd, Caracas, 1984, p.404.

4) Katritzky, A. R., Murugan, R., Balasubramanian, M., Greenhill, J. V., Siskin, M., Brons, G., Energy \& Fuels, 5, (6), 823 (1991).

5) Katritzky, A. R., Barcock, R. A., Balasubramanian, M., Greenhill, J. V., Siskin, M., Olmstead, W. N., Energy \& Fuels, 8, (2), 498 (1994)

6) Olobunmi, M., Ogunsola, Berkowitz, N., Fuel, 74, (10), 1485 (1995).

7) Kabe, T., Ishihara, A., Zhang, Q., Tsutsui, H., Tejima, H., J. Jpn. Petrol. Inst., 36, (6), 467 (1993).

8) Ma, X., Sakanishi, K., Mochida, I., Ind. Eng. Chem. Res., 33, 218 (1994)

9) Moriya, T., Enomoto, H., Polymer Degradation and Stability, 65, 373 (1999).

10) Gerdil, R., Lucken, E., J. Am. Chem. Soc., 87, 213 (1965).

11) Owens, P. J., Amberg, C. H., Adv. Chem. Ser., 33, 182 (1962).

12) Houalla, M., Broderick, D. H., de Beer, V. H. J., Gate, B. C., Kwart, H., Prepr. Am. Chem. Soc., Div. Petrol. Chem., 22, (3), 941 (1977).

13) Houalla, M., Broderick, D. H., Sapre, A. V., Nag, N. K., de Beer, V. H. J., Gate, B. C., Kwart, H., J. Catal., 61, 523 (1980).

14) Townsend, S. H., Abraham, M. A., Huppert, G. L., Klein, M. T., Paspek, S. C., Ind. Eng. Chem. Res., 27, 143 (1988). 
要旨

アルカリを添加した超臨界および带臨界水中でのベンゾチオフェン，ジベンゾチオフェン類の分解挙動

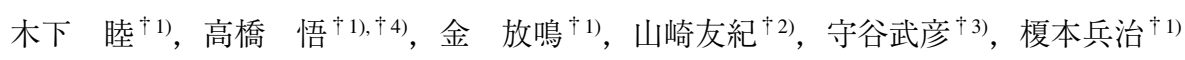

†1) 東北大学大学院環境科学研究科, 980-8579 仙台市青葉区荒巻字青葉 20

†2) 大阪府立工業高等専門学校, 572-8572 大阪府寝屋川市幸町 26-12

†3) 東北電力 (株) 研究開発センター, 981-0952 仙台市青葉区中山7丁目 2-1

†4）(現在）（独）石油天然ガス・金属鉱物資源機構 技術センター，261-0025 千葉市美浜区浜田 1 丁目 2 番 2 号

超臨界水を用いたビチューメンのオンサイト改質に抒ける脱 硫の促進を目的として, ベンゾチオフェン（BT）類とジベン ゾチオフェン（DBT）類のアルカリ水熱反応による分解を検討 した。BTおよびDBT類はアルカリ水熱処理で分解し，分解の 容易さはアルカリ水溶液の種類および濃度により影響を受け, $\mathrm{KOH}$ 水溶液中での分解が最も進行した。分解はある濃度で残 存率が最小となる極值を示した。また，水の超臨界状態では反 応圧力が高い方が分解は容易に進行した。BT類とDBT類の両 方について，本研究で報告した水熱分解とこれまでに他の研究
者によって報告されている水素化脱硫法（HDS）とで生成物が 異なり，また見かけの活性化エネルギーも大きく相違しており， 両分解法に扔いて反応機構が異なることが示唆された。BTは DBTよりも分解が容易に進行し，またメチル基を有する硫黄 化合物とメチル基を有さない硫黄化合物の分解の容易さを比較 すると,メチル基を有さない硫黄化合物の方が容易に分解する。 これらの傾向はHDSの場合と同様であり, 水熱分解の場合も 化合物の分子構造の影響を受けることがわかった。 